\title{
Post-harvest fungal diseases of guava: A brief review
}

\section{- DHONDIRAM GADGILE}

Department of Botany, Madhavrao Patil College, Palam, Tq- Palam, PARBHANI (M.S.) INDIA

Research chronicle : Received : 06.03.2017; Accepted : 30.05.2017

\section{SUMMARY :}

This review deals in detail about the post -harvest fungal diseases of guava fruits. Guava fruit is highly perishable so it suffers from a number of fungal diseases. Fungal diseases spoils guava fruits. Post-harvest fungi deteriorate the biochemical composition of fruit. Environmental factors viz., temperature and relative humidity affects the growth of post-harvest fungi. Several biological treatments has been tried for control the post-harvest fungi.

KEY WORDS : Guava, Post-harvest fungi, Fruit canker, Anthracnose, Fruit rot

How to cite this paper : Gadgile, Dhondiram (2017). Post-harvest fungal diseases of guava: A brief review. Internat. J. Proc. \& Post Harvest Technol., 8 (1) : 56-58. DOI: 10.15740/HAS/IJPPHT/8.1/56-58. 